\title{
PENERAPAN TEKNIK CHAIN MESSAGE COOPERATIVE UNTUK MENINGKATKAN AKTIVITAS DAN HASIL BELAJAR PESERTA DIDIK PADA PEMBELAJARAN IPS
}

\author{
Ida Nuridaliya \\ SMP Negeri 1 Jatinangor, email:
}

\begin{abstract}
ABSTRAK
Langkah penting yang harus dilakukan oleh seorang guru dalam kegiatan pembelajaran adalah memilih, menyederhanakan, menyesuaikan, menetapkan dan menyusun bahan pelajaran menjadi materi yang mudah dimengerti, dicerna dan diterima oleh peserta didik sehingga dapat mencapai perubahan perilaku yang diinginkan. Oleh karena itu guru sebagai pelaksana pembelajaran hendaknya dapat mengambil isi materi yang penting agar dapat melatih peserta didik dalam mengidentifikasi peristiwa-peristiwa atau fakta-fakta yang ada disekitarnya yang akhirnya peserta didik dilatih mengambil kesimpulan dalam rangka membentuk konsep. Dalam penelitian tindakan kelas ini peneliti sebagai guru bidang studi IPS berusaha meningkatkan aktivitas dan hasil pembelajaran dengan menerapkan model cooperative teknik 'chain message' yang dapat membangkitkan aktivitas belajar dan membantu mengatasi kesulitan peserta didik dalam memahami kompetensi usaha manusia memenuhi kebutuhan. Instrumen yang digunakan dalam penelitian ini terdiri dari Rencana Pelaksanaan Pembelajara (RPP), Alat Pembagi Kelompok, Leaflet, LKS, Lembar Observasi, Format Butir Soal, Penetapan Kriteria Ketuntasan Minimum, dan Angket. Penelitian Tindakan Kelas ini dilaksanakan di SMP Negeri 1 Jatinangor Kabupaten Sumedang, dengan subjek peserta didik kelas VII D. Pelaksanaan penelitian ini selama 4 bulan dimulai September sampai dengan Desember 2012 pada semester gasal tahun pembelajaran 20122013. Hasil penelitian menunjukkan aktivitas dan hasil belajar peserta didik mengalami peningkatan terutama pada siklus 2 mencapai $86 \%$. Hasil penilaian evaluasi dalam pemahaman konsep mengalami peningkatan hingga mencapai $82 \%$ pada siklus 2. Penerapan teknik Chain Message Cooperative dalam pembelajaran khususnya pada Kompetensi Memahami Usaha Manusia Memenuhi Kebutuhan sangat membantu guru maupun peserta didik meningkatkan aktivitas dan hasil pembelajaran Ilmu Pengetahuan Sosial.
\end{abstract}

Kata kunci: chain message,aktivitas, hasil belajar.

\section{PENDAHULUAN}

Seorang guru dalam melaksanakan kegiatan pembelajaran adalah memilih, menyederhanakan, menyesuaikan, menetapkan dan menyusun bahan pelajaran menjadi materi yang mudah dimengerti, dicerna dan diterima oleh peserta didik sehingga dapat mencapai perubahan perilaku yang diinginkan. Karena itu, guru sebagai pelaksana pembelajaran hendaknya dapat mengambil isi materi yang penting agar dapat melatih peserta didik dalam mengidentifikasi peristiwa-peristiwa atau fakta-fakta yang ada disekitarnya yang akhirnya peserta didik dilatih mengambil kesimpulan dalam rangka membentuk konsep.

Dalam pelaksanaan pembelajaran IPS tahun lalu di SMP Negeri 1 Jatinangor khususnya peserta didik kelas VII masih mendapat kesulitan untuk mencapai hasil yang maksimal; rendahnya kesiapan peserta didik terhadap pembelajaran IPS; terbatasnya daya pengingat peserta didik, kurangnya konsentrasi dalam proses pembelajaran; sedikit peserta didik yang memiliki kemampuan untuk mempunyai buku-buku penunjang pembelajaran IPS, terbukti dari perilaku peserta didik yang pasif dan pencapaian hasil pembelajaran sebanyak 76 $\%$ peserta didik memperoleh nilai kurang dari KKM (Kriteria Ketuntasan Minimum). Berangkat dari permasalahan tersebut maka penulis melakukan Penelitian Tindakan Kelas dengan latar belakang sulitnya peserta didik menyerap kompetensi usaha manusia memenuhi kebutuhan pada mata pelajaran IPS. Sebagai 
guru bidang studi IPS, peneliti berusaha meningkatkan aktivitas dan hasil pembelajaran dengan menerapkan model cooperative teknik 'chain message' yang diduga akan membangkitkan aktivitas belajar dan membantu mengatasi kesulitan peserta didik dalam memahami kompetensi usaha manusia memenuhi kebutuhan.

Dari latar belakang yang telah dipaparkan di atas, maka penelitian ini bermaksud untuk mengidentifikasi: 1) Apakah teknik chain message cooperative dapat meningkatkan aktivitas dan hasil belajar peserta didik pada kompetensi usaha manusia memenuhi kebutuhan? 2) Bagaimana proses peningkatan aktivitas dan hasil belajar peserta didik pada kompetensi usaha manusia memenuhi kebutuhan dengan menggunakan teknik chain message cooperative? 3) Seberapa besar peningkatan aktivitas dan hasil belajar peserta didik pada kompetensi usaha manusia memenuhi kebutuhan dengan menggunakan teknik chain message cooperative?

Penelitian Tindakan Kelas ini bertujuan untuk: 1) Mengetahui peningkatkan aktivitas dan hasil belajar peserta didik pada kompetensi usaha manusia memenuhi kebutuhan dengan menerapkan teknik chain message cooperative; 2) Mengetahui proses peningkatkan aktivitas dan hasil belajar peserta didik pada kompetensi usaha manusia memenuhi kebutuhan dengan menerapkan teknik chain message cooperative; 3). Mengetahui seberapa besar aktivitas dan hasil belajar peserta didik pada kompetensi usaha manusia memenuhi kebutuhan dengan menggunakan teknik chain message cooperative.

Bagi peserta didik, PTK ini diharapkan: 1) Teratasinya kesulitan dalam memahami kompetensi usaha manusia memenuhi kebutuhan; 2) Meningkatnya minat dan rasa senang terhadap mata pelajaran IPS; 3) Meningkatnya aktivitas dan hasil belajar peserta didik.

Bagi guru, PTK ini diharapkan dapat: 1) Memberikan masukan dalam hal penentuan metode dan strategi pembelajaran dalam KBM mata pelajaran IPS di SMP; 2) Menanamkan pemahaman bahwa untuk mencapai tujuan pembelajaran yang optimal dan efisien diperlukan suatu strategi pembelajaran yang tepat; 3) Menjadi kontribusi bagi guru setempat dalam memilih model pembelajaran yang akan digunakan untuk meningkatkan aktivitas dan hasil belajar.

Bagi sekolah, PTK ini diharapkan dapat: 1) Memberikan alasan dan argumentasi bagi kebijakan yang akan diambil guna peningkatan aktivitas dan hasil belajar; 2) Meningkatnya kerjasama antar guru dalam upaya memecahkan masalah pembelajaran guna peningkatan profesionalisme; 3) Meningkatnya pengetahuan dan motivasi guru IPS dari pengalaman penelitian tindakan; 4) Meningkatnya kompetensi lulusan peserta didik melalui peningkatan aktivitas dan hasil belajar.

\section{METODE PENELITIAN}

Penelitian tindakan kelas ini menggunakan metode deskriptif analitis melalui yaitu studi yang digunakan untuk mengumpulkan, mengolah, menganalisa, menafsirkan, dan menyimpulkan data sehingga diperoleh gambaran yang sistematis dalam peningkatan aktivitas dan hasil belajar peserta didik. Model yang dikembangkan dalam penelitian tindakan kelas ini terdiri atas empat tahap, yaitu 1) perencanaan (planning), 2) pelaksanaan tindakan (action), 3) pengamatan (observing), dan 4) refleksi (reflecting).

Penelitian dilakukan di kelas VII D SMPN 1 Jatinangor Kabupaten Sumedang, Semester 1 tahun pelajaran 2012-2013. Jumlah peserta didik kelas VII D sebanyak 38 orang terdiri dari 21 laki-laki dan 17 perempuan. Secara keseluruhan merupakan kelas dengan karakteristik yang beragam baik dari segi sosial-ekonomi, kecakapan maupun prestasi lainnya. Instrumen penelitian yang digunakan antara lain kartu soal yang digunakan dalam teknik chain message cooperative, soal uji kompetensi peserta didik, lembar observasi guru, dan lembar observasi peserta didik.

Rumusan hipotesis dalam penelitian tindakan ini memuat jika teknik chain message 
cooperative diterapkan pada kompetensi usaha manusia memenuhi kebutuhan dalam konteks pembelajaran IPS maka aktivitas dan hasil belajar peserta didik akan meningkat.

\section{HASIL DAN PEMBAHASAN Pelaksanaan pra-siklus}

Setelah mengucapkan salam dan memeriksa kehadiran guru membagi peserta didik kelas VII D yang berjumlah 38 orang terdiri dari 20 laki-laki dan 18 perempuan menjadi dua kelompok besar; kelompok pertama menempati ruangan dengan posisi duduk satu bangku untuk satu orang peserta didik dimaksudkan agar diperoleh hasil optimal se-objektif mungkin, sedang kelompok lainnya berada di luar ruangan menunggu giliran jam berikutnya; setiap kelompok diberi waktu satu jam pelajaran (40 menit).

Guru membagikan soal terdiri dari 15 butir multiple choise (pilihan ganda) dengan skor nilai per-soal adalah 2 dan 6 butir uraian dengan skor nilai 20, jadi skor nilai keseluruhan adalah 50 kemudian dikalikan 2 hingga setiap peserta didik memperoleh nilai maksimum 100 .

Hasil yang tidak memuaskan karena sebanyak $76 \%$ peserta didik memperoleh nilai dibawah standar ketuntasan (KKM) yang telah ditetapkan yaitu 70 dan hanya $24 \%$ saja yang berhasil mencapai ketuntasan belajar yakni memperoleh nilai diatas 70 .

\section{Pelaksanaan Siklus ke satu (1)}

Kegiatan di kelas pada pertemuan pertama ini dimulai dengan pembelajaran tentang kreativitas dalam tindakan ekonomi setelah sebelumnya memeriksa kehadiran. Kemudian menuliskan kompetensi yang ingin dicapai yakni manusia sebagai makhluk sosial dan makhluk ekonomi yang bermoral; dengan tujuan pembelajaran mencakup Menjelaskan pengertian manusia ekonomi (homo economicus), Mengidentifikasi makna manusia sebagai makhluk sosial (homo socius) dan makhluk ekonomi yang bermoral, mendeskripsikan hakekat manusia sebagai makluk Sosial dan makhluk ekonomi yang bermoral.
Langkah selanjutnya guru menguraikan tahapan kegiatan yang akan dilalui peserta didik mulai dari pembagian kelompok sampai pada langkah-langkah penerapan teknik chain message. Peserta didik dibagi menjadi enam kelompok besar terdiri dari $6-7$ orang; Setiap anggota kelompok diberi nomor urut, pemegang kartu nomor 1 berdiri paling depan. Guru memberikan nilai dari kinerja individu dan kelompok tersebut dengan ketentuan semakin besar nomor anggota mampu menyelesaikan pesan/soal semakin besar nilainya. Deskripsi penilaian aktivitas mencakup empat unsur yang dinilai meliputi aktivitas, menyampaikan, mendengarkan, dan menjawab (tabel 1).

Tabel 1. Skor Penilaian Aktivitas

\begin{tabular}{lcc}
\hline Kategori & Rentang skor & Kriteria Nilai \\
\hline Sangat Baik & $90-100$ & A \\
\hline Baik & $75-89$ & B \\
\hline Cukup & $65-74$ & C \\
\hline Kurang & $50-64$ & D \\
\hline
\end{tabular}

Guru memeriksa arus pesan/informasi untuk mengetahui pada peserta didik mana terjadi error message dengan cara meminta anggota kelompok tersebut menyebutkan kembali pesan/soal secara berurutan dimulai dari nomor 1. Peserta didik yang menjadi penyebab kesalahan (trouble maker) diberi nilai minus 1 dari nilai kelompoknya.

Peserta didik yang mengikuti tes berjumlah 38 orang, mencapai KKM sebanyak 22 orang dan sisanya sebanyak 16 orang masih belum mencapai ketuntasan minimum, peserta didik yang memiliki nilai di atas rata-rata sebanyak 20 orang sedangkan yang masih di bawah rata-rata sebanyak 18 orang, kelas ini memperoleh rata-rata hasil penilaian sudah di atas ketuntasan minimum yakni 72,16. Hasil yang diperoleh peserta didik dengan nilai terkecil 53 dan nilai terbesar mencapai 89. Prosentase ketuntasan belajar peserta didik kelas VII D baru mencapai $58 \%$ pada siklus 1 .

\section{Pelaksanaan Siklus ke-dua (2)}

Mengawali pertemuan dengan mengucapkan salam dan doa bersama, diteruskan dengan 
memeriksa kehadiran. Untuk menciptakan suasana belajar yang baik guru melakukan appersepsi dengan mengemukakan pertanyaan sebagai pengetahuan prasyarat "Apa yang menjadi permasalahan ekonomi ?..........." Guru membangkitkan motivasi dan kesiapan belajar peserta didik dengan menginformasikan kompetensi yang ingin dicapai terdiri dari Mendeskripsikan perilaku manusia dalam memanfaatkan sumber daya yang terbatas untuk memenuhi kebutuhan hidupnya, Mendeskripsikan berbagai tindakan ekonomi rasional yang dilakukan manusia. Dengan peta konsep guru menjelaskan tentang pemanfaatan sumber daya untuk memenuhi kebutuhan dengan tindakan ekonomi rasional dengan ceramah bervariasi.

Selanjutnya guru menginformasikan agar peserta didik menyiapkan diri untuk masuk ke sesi pesan berantai (chain message) dari materi tersebut. Dibentuk kelompok yang baru berdasar-kan gender dimaksudkan agar pada saat membisikkan pesan peserta didik tidak merasa canggung dan akan merasa leluasa bergerak walaupun harus berdekatan dan bersentuhan. Berikut grafik (gambar 2) merupakan rekapitulasi hasil penilaian aktivitas pembelajaran dengan teknik chain message pada siklus 2 .

Tidak berbeda dengan siklus 1 kali inipun peserta didik diberi lembar soal terpisah dengan lembar jawaban dan mereka hanya boleh melakukan pengisian jawaban pada lembar yang telah disediakan (terdapat pada lampiran). Waktu yang disediakan untuk kegiatan ini satu jam pelajaran (40 menit) perkelompok. Setelah kelompok pertama menyelesaikan tes maka giliran kelompok selanjutnya untuk melakukan kegiatan yang sama. Pada akhir kegiatan guru mengumpulkan soal dan jawaban untuk diperiksa. Setelah dilakukan pemeriksaan hasil ulangan dibagikan kepada peserta didik untuk diketahui orang tua masing-masing.

Peserta didik mengikuti tes berjumlah 38 orang, yang mencapai KKM terdapat peningkatan dari siklus pertama sebanyak 9 orang seluruhnya terdapat 31 peserta didik dengan ketuntasan mencapai $82 \%$ dari 38 peserta didik. dan sisanya sebanyak 7 orang masih belum mencapai ketuntasan minimum, peserta didik yang memiliki nilai di atas rata-rata sama dengan di bawah rata-rata kelas yakni sebanyak 19 orang, rata-rata kelas ini sudah melapaui ketuntasan minimum yakni 76,76. Hasil yang diperoleh peserta didik dengan nilai terkecil 58 dan terbesar mencapai 100 (gambar 3).

\section{Refleksi}

Hasil pengamatan yang diperoleh selama proses tindakan ditemukan beberapa hal sebagai berikut: Sebagian besar peserta didik sudah terlihat antusias terjadi peningkatan dari siklus 1, selain mengemukakan pertanyaan tampak tidak sabar ingin menjawab pertanyaan yang diajukan terbukti dari banyaknya yang menunjuk tangan; Setelah mengalami dan melalui kegiatan chain message pada siklus 1 peserta didik menginginkan untuk dilakukan perombakan struktur kelompok dan perubahannya terjadi perbedaan gender antara kelompok laki-laki dan perempuan; Peserta didik terlihat lebih enjoy dan menikmati pembelajaran yang tengah dihadapi saat berperan sebagai pelaku kegiatan chain message maupun saat menjadi juri atau menunggu giliran; Tidak lagi terjadi kebosanan pada peserta didik saat melakukan pengamatan kelompok yang tengah melakukan kegiatan di depan kelas karena guru sudah menyiapkan lembar kerja bagi peserta didik yang menunggu giliran; Tetap sibuk menyiapkan diri dan mengatur kelompoknya untuk menentukan posisi jika mendapat giliran melakukan kegiatan di depan kelas; Senantiasa membuka buku pegangan dan buku catatan dan berusaha mengingat apa yang tengah dibaca atau menghafal konsep-konsep; Guru sudah menyediakan peta konsep tentang Manusia sebagai Makhluk Sosial dan Ekonomi yang Bermoral dalam memenuhi kebutuhan dan Tindakan Pokok Ekonomi; Tidak terdapat masalah dalam kehadiran pada siklus 2 ini mencapai $100 \%$.

Peserta didik yang memperoleh hasil belajar di atas ketuntasan minimum belum 
memuaskan baru mencapai $82 \%$ dari 38 peserta didik; Rata-rata kelas mencapai 76,76; peserta didik yang memperoleh nilai diatas rata-rata sebanyak 19 orang sama dengan peserta di bawah rata-rata kelas. Sebagian besar peserta didik menunjukan peningkatan aktivitas dengan memperoleh kriteria amat baik (A) 34,2\%, kriteria baik (B) 60,5\%, dan kriteria cukup (C) sebesar 5,3\% terjadi peningkatan yang signifikan pada kriteria A sebesar $21 \%$ dan penurunan pada kriteria B $10,5 \%, \mathrm{C} 7,9 \%$ dan D sebesar 2,6 \%. Rekapitulasi nilai keaktifan dapat dilihat pada tabel 2.

\section{PENUTUP}

Simpulan penelitian adalah sebagai berikut: 1) Terdapat peningkatan aktivitas dan hasil belajar peserta didik pada pembelajaran IPS khususnya kompetensi memahami usaha manusia memenuhi kebutuhan dengan menerapkan teknik chain message; 2) Proses peningkatan aktivitas dan hasil belajar meliputi kegiatan persiapan, pelaksanaan dan penilaian. Persiapan yang matang dan instrumen yang lengkap memudahkan proses pelaksanaan tindakan di kelas menggunakan teknik chain message selama 2 siklus dengan hasil menunjukan peningkatan baik hasil maupun aktivitas selama proses penelitian berlangsung dari mulai kegiatan pra-siklus, siklus 1 dan siklus 2; 3) Penerapan teknik chain message ternyata dapat meningkatkan aktivitas dan hasil belajar yang jauh lebih memuaskan daripada penggunaan metode ceramah saja.

Penelitian ini menenjukkan aktivitas peserta didik mengalami peningkatan 50\% dengan kriteria sangat baik (A) dan $50 \%$ baik (B), sedangkan hasil belajar peserta didik khususnya kompetensi memahami usaha manusia memenuhi kebutuhan meningkat sampai $82 \%$.

Sebagai saran penelitian: 1) Profesionalisme seorang guru dalam mengelola kegiatan pembelajaran harus selalu ditingkatkan baik melalui pelatihan, workshop, MGMP atau melanjutkan pendidikan ke jenjang yang lebih tinggi; 2) Guru diharapkan mengembangkan situasi kondusif dalam mengelola kelas dan selalu mengikuti perkembangan informasi yang mutakhir, khususnya yang berhubungan dengan mata pelajaran IPS; 3) Guru senantiasa inovatif dan kreatif menciptakan model-model dan teknik pembelajaran agar peserta didik selain dapat dengan mudah menyerap dan memahami materi pembelajaran juga dapat merasakan suasana proses pembelajaran yang tidak monoton dan menjenuhkan; 4) Persiapan pembelajaran yang matang dan lengkap memungkinkan guru lebih mudah dan peserta didik lebih cepat memahami konsep-konsep pembelajaran. Karena itu kepada rekan guru untuk senantiasa menyiapkan perangkat pembelajaran sebagaimana yang dibutuhkan.

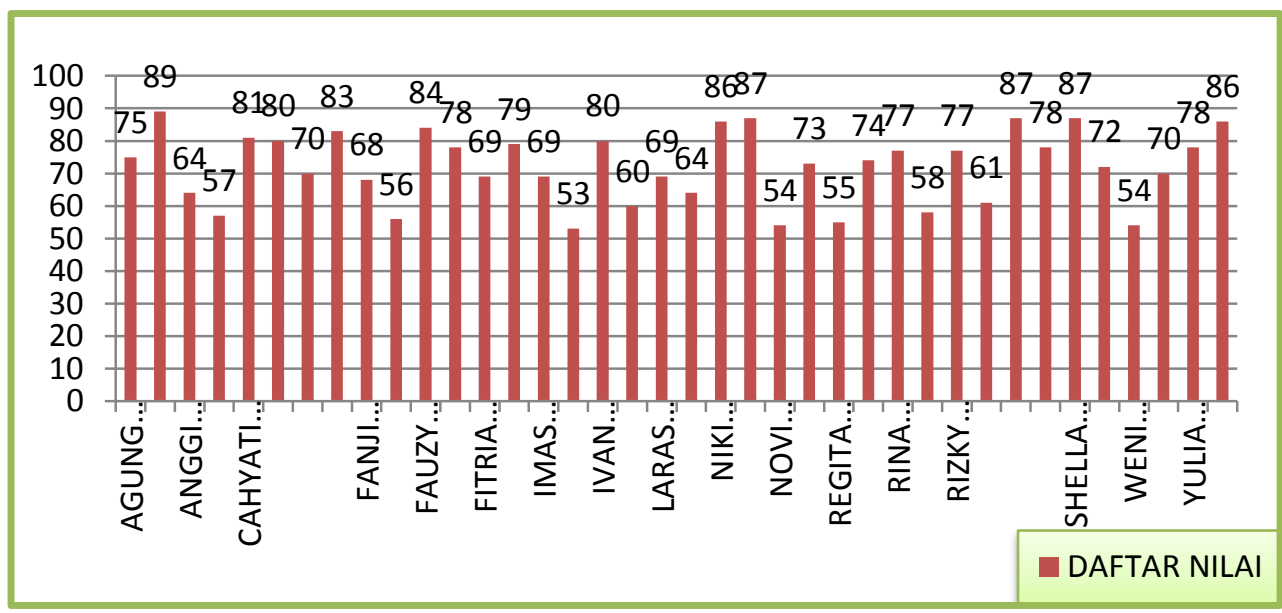

Gambar 1. Hasil KKM 


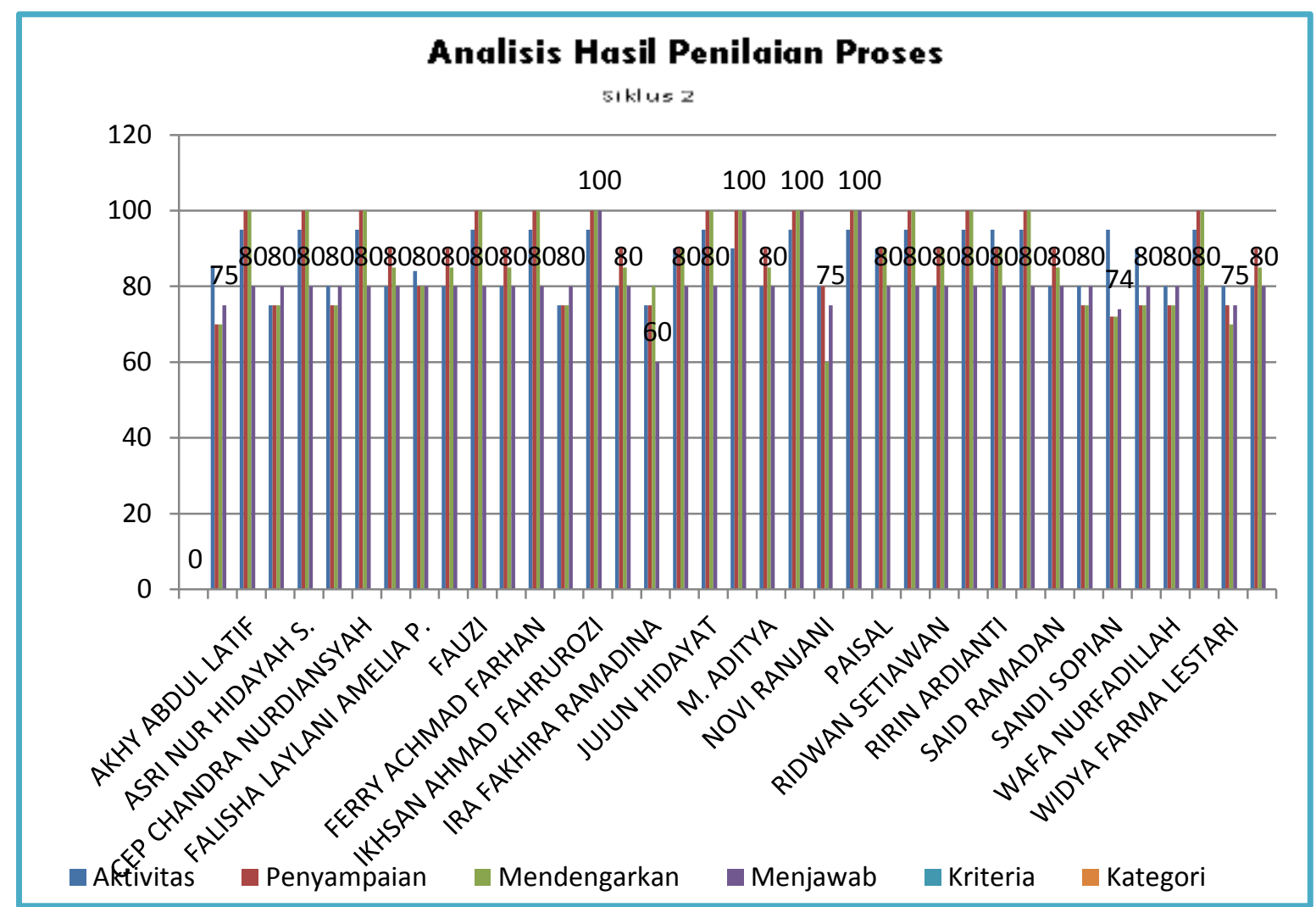

Gambar 2. Rekapitulasi Hasil Penilaian Aktivitas

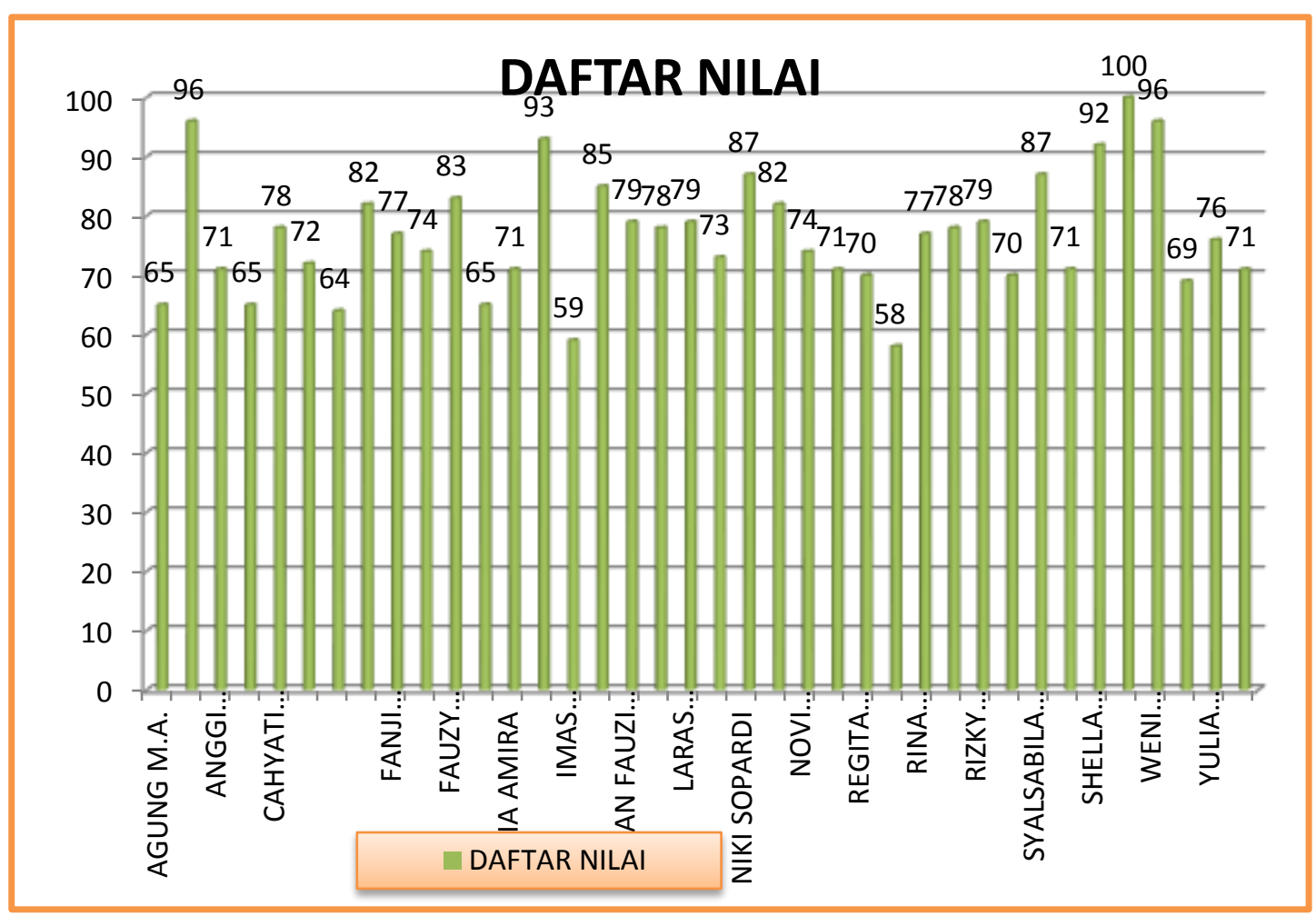

Gambar 3. Pencapaian KKM 
Tabel 2. Rekapitulasi Nilai Keaktifan Kelompok

\begin{tabular}{|c|c|c|c|c|c|c|}
\hline \multirow{2}{*}{ NO } & \multirow{2}{*}{ KEGIATAN } & \multicolumn{4}{|c|}{ NILAI AKTIVITAS } & \multirow{2}{*}{ JML } \\
\hline & & A & $\mathrm{B}$ & $\mathrm{C}$ & $\mathrm{D}$ & \\
\hline \multirow{2}{*}{1} & \multirow{2}{*}{ Siklus 1} & 5 & 27 & 5 & 1 & 38 \\
\hline & & $13,2 \%$ & $71,1 \%$ & $13,2 \%$ & $2,6 \%$ & $100 \%$ \\
\hline \multirow{2}{*}{2} & \multirow{2}{*}{ Siklus 2} & 13 & 23 & 2 & - & 38 \\
\hline & & $34,2 \%$ & $60,5 \%$ & $5,3 \%$ & - & $100 \%$ \\
\hline \multicolumn{2}{|c|}{ Selisih Prosentase } & $21 \%$ & $10,5 \%$ & $7,9 \%$ & $2,6 \%$ & \\
\hline
\end{tabular}

\section{DAFTAR PUSTAKA}

Awal dan Wijaya Kusumah, April, 22, 2008. 3.16 am. Materi Pelatihan KTSP 2009, Depdiknas, pp. Jakarta

Depdiknas. 2003. Undang-Undang Republik Indonesia Nomor 20 Tahun 2003 Tentang Sistem Pendidikan Nasional, Biro Hukum dan Organisasi, SekJen. Depdiknas. Jakarta.

Depdiknas, Dirjen DikDasMen, Direktorat PLP. 2005. Ilmu Pengetahuan Sosial, Buku 4, Materi Pelatihan Terintegrasi, Jakarta.

Didang Setiawan. 2008, Pengetahuan Sosial 1, untuk SMP/M.Ts, Pusat perbukuan Depdiknas. Jakarta.

Etin Solihatin.Hj.Dra. dan Raharjo, M.Pd., 2005, Cooperative Learning, Analisis Model Pembelajaran IPS, Jakarta, Bumi Aksara.

Fuad Hasan et al. 1993. Kurikulum Pendidikan Dalam Proses Belajar dan Mengajar. Jakarta : Bina Aksara.

Instruktur PTBK. 2005. Materi Pelatihan Terintegrasi Berbasis Kompetensi, Bandung.

I Wayan Legawa dkk, 2008, CTL Ilmu Pengetahuan Sosial, Sekolah Menengah Pertama Kelas VII edisi 4, Pusat perbukuan. Depdiknas. Jakarta

Iwan Setiawa, dkk., 2008. Wawasan Sosial 1, IPS untuk kelas VII SMP/ M.Ts, Pusat perbukuan. Depdiknas. Jakarta

Muchlas Samani, Prof. Dr. dkk. 2003. Pembinaan Profesi Guru, Direktorat PLP, Dirjen Dikdasmen, Depdiknas, Jakarta.
Nasution, S. 1987. Berbagai Pendekatan Dalam Proses Belajar dan Mengajar. Jakarta : Bina Aksara.

Nugroho Notosusanto. 1982. Petunjuk Guru Sejarah Nasional Indonesia. Jakarta : Depdikbud.

Nurhadi, Dr.,M.Pd. dkk. 2003. Pembelajaran Kontekstual, dan Penerapannya dalam kbk. Malang. Universitas Negeri Malang

Oemar Hamalik. 1990. Metoda Belajar dan Kesulitan-Kesulitan Belajar. Bandung : Tarsito.

PusKur, Balitbang, Depdiknas, Model Pembelajaran IPS Terpadu, SMP/MTs, Jakarta.

Rochiati Wiriaatmaja, Prof. Dr., 2005, Metode Penelitian Tindakan Kelas, PT Remaja Rosdakarya, Bandung

Rustam dan Mundilarto. 2004. Penelitian Tindakan Kelas, Direktorat Pembinaan Pendidikan Tenaga Kependidikan dan Ketenagaan PT, Dirjen DikTi, Depdiknas, Jakarta.

Sarosa Purwadi. 1980. Metoda-Metoda Mengajar. Jakarta : Proyek Pengembangan Pendidikan Guru.

Tabrani Rusyan, A. et al. 1990. Penuntun Belajar yang Sukses. Jakarta : Ning Karya Jaya.

Waluyo dkk. 2008, Ilmu Pengetahuan Sosial, untuk SMP/ M.Ts kelas VII Pusat perbukuan Depdiknas. Jakarta.

Zainal Aqib, 2006, Penelitian Tindakan Kelas, Bandung, Yrama Widya.

IIID/SSN/Materi SSN/ April,22, 2008, Modelmodel Pembelajaran « Labschool. Jakarta.htm. 